\title{
Coexistence of Business Continuity Management and Controlling: Controlling use as a moderator of relation between BCM maturity and organizational results
}

\author{
Katarzyna Tworek \\ Assistant professor, Wroclaw University of Science and Technology, Faculty of Computer Science and \\ Management, wyb. Wyspianskiego 27, 50-370 Wroclaw, POLAND, katarzyna.tworek@pwr.edu.pl \\ Agnieszka Bieńkowska \\ Professor of WUST, Wroclaw University of Science and Technology, Faculty of Computer Science and \\ Management, wyb. Wyspianskiego 27, 50-370 Wroclaw, POLAND, agnieszka.bienkowska@pwr.edu.pl \\ Anna Zabłocka-Kluczka \\ Assistant professor, Wroclaw University of Science and Technology, Faculty of Computer Science and \\ Management, wyb. Wyspianskiego 27, 50-370 Wroclaw, POLAND, anna.zablocka-kluczka@pwr.edu.pl
}

Received (23.11.2018.); Revised (09.01.2019.); Accepted (04.02.2019.)

\begin{abstract}
The paper is devoted to the analysis of the influence of Controlling use on Business Continuity Management (BCM). The analysis concentrates on BCM maturity and its influence on organizational results. It is assumed that Controlling use is one of factors influencing that relation. Empirical research is conducted to verify formulated hypotheses based on results obtained from more than 1000 organizations from two business contexts (Poland and Switzerland) in order to determine whether Controlling use is a moderator of the relation between BCM maturity and organizational results.
\end{abstract}

Key words: Business Continuity Management, BCM Maturity, Controlling, management, organizational results

\section{INTRODUCTION}

Business management in a changing and increasingly unpredictable environment, as well as the complexity and dynamics of modern management systems, requires the use of different concepts and methods of management [21]. Therefore, it is not surprising that nowadays there is a growing "supply" of new solutions in the discussed area. It is true that sometimes their characteristic is combining and using many already known tools and methods of management, and "the value of originality or novelty can only be attributed to the creative combination, displaying specific ideas or tools, often far from each other and not associated with each other" [21], but even this combination or exposure of selected parts of methods can be an added value for the organization as a whole. What is more, Lichtarski and Czura note that the presence of different management concepts is "one of the features that can be used to describe and differentiate management systems" [26].

It should be noted that with the emergence of many new concepts and methods of management, the problem of their coexistence in the organization arises, including the need for determination of relations between these methods. Management methods can be complementary, substitutive, contradictory or incomparable [7]. The complementarity of methods means complementing methods or their elements so that they form a logical whole. The complementary methods can be equal to each other, when their coexistence allows to better implement specific organizational goals or one of the methods can be superior to the other, then the subordinate method is an instrument for the superior one in serving the achievement of specific goals. The substitutability of methods means that they are an alternative for each other from the perspective of specific organizational goals. The contradiction of methods means that assumptions, goals, key principles or ways of acting are mutually exclusive, and therefore their simultaneous use is counter-effective. Finally, incomparability of methods means that they remain without a clear relation, relate to different objectives and / or affect different areas of the organization's operations [7].

Analysis of the relations between contemporary concept and methods of management is not only an issue that is current, it is also important for the practice of management. First of all, because the coexistence of different concepts and methods of management is a fact [7]. Moreover, according to Lichtarski and Czura [26], as a result of implementing two or more concepts at the same time, it is possible to achieve such benefits (the synergy effect) which would not be achieved if the concepts were used separately. 
This article discusses the issue of the coexistence of Business Continuity Management (BCM) and Controlling. BCM is understood as "a holistic management process that identifies potential impacts that threaten an organization and provides a framework for building resilience with the capability for an effective response that safeguards the interests of key stakeholders, reputation, brand and value creating activities" [35]. Controlling is considered as a comprehensive method which - in a holistic way supports the management system of an organisation [24] Perovic [33] [34]. Controlling is also a method that often coexists with other management methods, most often entering into complementarity (e.g. BSC, benchmarking, TQM, BPM) or substitutability (e.g. Six Sigma) relations with them [6]. Therefore, the aim of the article is to determine and empirically verify the scope and character of the relation between BCM and Controlling, as well as to identify the results of this coexistence. The organizational performance measurement will serve as an indicator of the type of relation between analyzed methods [8]. It is assumed for complementary methods that the resulting parameters of organizations, in which both methods have been implemented, are higher than in organizations, in which one method has been implemented or none have been implemented. The simultaneous use of substitutive methods can, admittedly, positively influence the achievement of a narrow group of organizational goals (to a small extent only). However, it will lead to decrease of other organizational results (it is expensive and more difficult organizationally). The simultaneous use of contradictory methods negatively influences the functioning of the organization as a whole. The implementation of incomparable methods should not affect the assessment of organizational results, which should be achieved by each method [7]. It should be also emphasised that the issue of the coexistence of BCM and Controlling and its empirical verification is not yet discussed in the literature.

\section{BCM AND CONTROLLING - A CHARACTERISTIC AND A TYPE OF RELATION}

BCM is intended as some set of activities aimed at securing the continuity of an organization's operations in the event of a disruption. It is a socio-technical approach focused on identifying and preventing operational risks [19]. Technical aspects of building business continuity „include plans and alternative arrangements that enhance organizational alertness and preparedness. Embedding continuity practices in the organization refers to social factors such as the commitment of the personnel" [22] or building the culture of maintaining business continuity. When implementing $\mathrm{BCM}$, organizations expect to strengthen the organization's resilience, i.e. reduce the vulnerability to risk, and the ability to quickly resume operations in the event of disruptions. In particular, the expected benefits can be referred to ensuring continuity of technological operations, which in turn is the basis for ensuring continuity of operational / business, market and financial operations [38]. Usually, the main focus is put on BCM to create system solutions that enable business continuity, but it should be emphasized that indirectly this also has an impact on the effectiveness of the entire organization, thus assuring business continuity in critical way determinates achieving organization's goals, as even small breakdowns in a business continuity brings risk for revenue, shareholder trust and customer loss [38]. Hence, BCM may brings „....many benefits to the organization and relevant stakeholders. These benefits may be direct, like reducing failures and disasters, or indirect, like improving performance and the perception of the organization" [1]. Therefore, following hypothesis may be formulated:

$\mathrm{H} 1$ : In organizations, which have implemented BCM, the organizational performance is higher than in organizations, which have not implemented BCM.

„BCM is maturing discipline. Although its origins lie in Information Systems (IS) protection, it is evolving into a full business-wide process" [16]. The process of achieving maturity in BCM is associated with improvement of organizational skills and instruments used in this area. Both the tools and instruments of BCM (such as i.e. risk analysis, business impact analysis or business continuity planning) and ways of using them has been developed over the years. As the time went by BCM changed from simple disaster recovery planning, through the more comprehensive contingency planning to business continuity planning and then management, covering the full spectrum of the business enterprise.

The quality and range of implemented BCM solutions (BCM maturity) influences the scope of benefits obtained due to BCM implementation, what already was proofed [39]. Assuming, that in general, striving for perfection in every operational area determines the development and effectiveness of the organization [37], also maturation of BCM solutions should contribute to the improvement of the organization's performance. Based on that, following hypothesis may be formulated: $\mathrm{H} 2(a b c d f):$ There is a positive relation between the $B C M$ maturity (in particular maturity of solutions in all phases of BCM cycle: risk analysis (a), business impact analysis (b), BCM plans and strategies (c), BCM implementation (d), testing and updating BCM (e) and maintaining BCM (f)) and the organizational performance.

Controlling, as one of the method of management, which is most often used in contemporary organizations [5], is understood as "a method of management support used mainly in the areas of planning and Controlling for the implementation of functions such as information supply, coordination, supervision, monitoring or participation in management; enabling managers through its measurable and economical overtone - for making rational (and apt) decisions, and thus aimed at achieving the goals of the organization as a whole" [4]. Weber [44] also notes that Controlling can be defined as steering support which provides organization managers with essential help. Hence, Controlling supports clear determination of the aims to be achieved 
as well as fast verification of problem areas in the organisation [27]. In addition, the implementation of Controlling allows for achieving measurable, often economic benefits in the organization. It improves the effectiveness and competitiveness of organizations functioning [29] and allows the organization to achieve not only economic efficiency (profitability) and financial liquidity [18], but management effectiveness and efficiency as well [43]. Therefore, the following hypothesis can be formulated:

H3: In organizations, which have implemented Controlling, the organizational performance is higher than in organizations, which have not implemented Controlling.

Moreover, Controlling supports organizations continuity and development [3]. Its strategic goal is to ensure the continuity of the organization and stimulate its development [3], although in a different way than BCM. Therefore, the steering area of Controlling is important - understood as responding to anticipated or anticipated deviations by developing corrective or preventive decisions that will enable the organization to achieve the previously set goals. One of its tools is the early warning system. Controlling is therefore "oriented towards finding and showing cause-and-effect relations of phenomena occurring both in the environment and within the organization" [23], and steering is the most important reference area for Controlling. Moreover, one of the assumptions regarding the implementation of Controlling in the organization is making changes in the organization with particular emphasis on the identified bottlenecks [42]. Thus, the structuring and regularity of Controlling, its strong focus on ensuring the long-term future of the organization (i.e. orientation towards the future and improvement) brings the goals of Controlling closer to the goals of the BCM. However, it must be underlined that BCM should not be an accidental, onetime operation, but continuously repeated set of actions taken to achieve a given purpose: to maintain the continuity of the organization. This led to the search for system solutions in that field. In practice, hence, BCM refers to: anticipating of possible threats and interruptions (assessing the strength of their impact and the risks they carry), planning for business continuity maintenance and testing the plans, and in the same time monitoring deviations from standards recognized as safe and responding if necessary. The whole process ends with learning and embedding the philosophy of continuity into organization. Lately, the necessity of BCM assimilation into day-to-day (operational) management, is strongly emphasized [16]. According to taken BCM definition, BCM provides a framework for building resilience. And assuming, among others [25], that this resilience can also be economic, it seems that BCM and Controlling will have a very similar role, often using even the same tools. In the above context, the complementarity of both management methods may be assumed. At the same time, it seems that BCM is superior to Controlling, which in fact means that Controlling is a tool for BCM to achieve its goals. Therefore, the following hypothesis can be formulated:
H4a: In organizations, which have declared the simultaneous implementation of BCM and Controlling, the organizational performance will be higher than in organizations, which have implemented only one of the analyzed methods.

H4b: In organizations, which have declared the simultaneous implementation of BCM and Controlling, benefits obtained due to BCM implementation are higher than in organizations, which have implemented $B C M$ and have not implemented Controlling.

Moreover, it seems that Controlling use may moderate the organization ability to increase benefits obtained due to BCM implementation and, at the end, organizational performance. Moreover, it seems that the maturity of BCM solutions is enabling that moderation. The relation between $\mathrm{BCM}$ maturity and benefits obtained due to its implementation, which seems to confirm that assumption, was already analyzed by Tworek and Zabłocka-Kluczka [39]. However, it seems that Controlling may be a moderator, which strengthens that relation and as the result, the relation between BCM maturity and organizational performance. Therefore, it can be assumed that Controlling is a moderator of the relation between BCM maturity and organizational performance. The following hypotheses may be formulated:

H5(abcdef): In organizations, which have implemented Controlling, the BCM maturity (in particular maturity of solutions in all phases of BCM cycle: risk analysis (a), business impact analysis (b), BCM plans and strategies (c), BCM implementation (d), testing and updating BCM (e) and maintaining BCM (f)) influence on benefits obtained due to BCM implementation is stronger than in organizations, which have not implemented Controlling. H6(abcdf): In organizations, which have implemented Controlling, the BCM maturity (in particular maturity of solutions in all phases of BCM cycle: risk analysis (a), business impact analysis (b), BCM plans and strategies (c), BCM implementation (d), testing and updating BCM (e) and maintaining $B C M(f))$ influence on organizational performance is stronger than in organizations, which have not implemented Controlling.

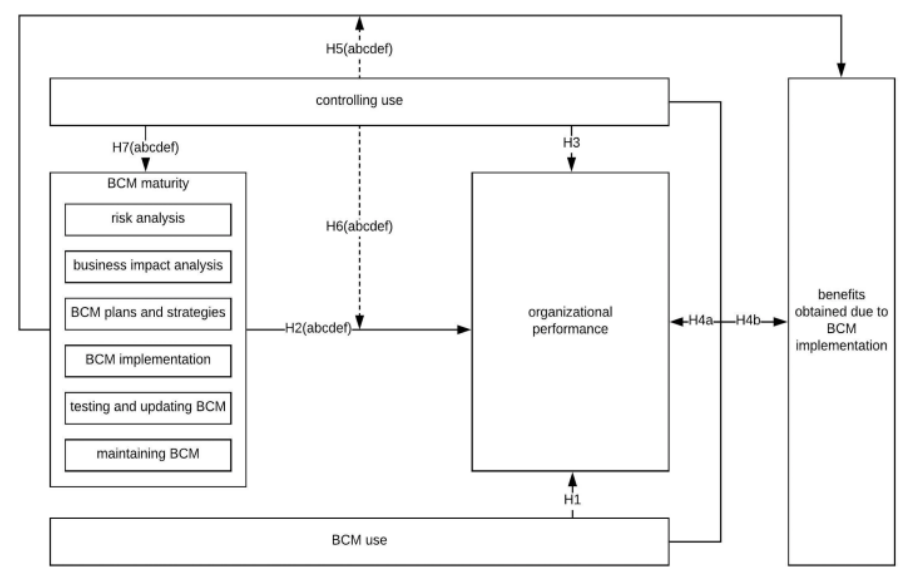

Figure 1. Controlling and BCM influence on organizational results. Source: own research 
As a result, it should also be underlined, as de facto a specific seal of the relation of complementarity and subordination of Controlling to BCM, that:

H7(abcdf): In organization, which have implemented Controlling, the maturity of BCM (in particular maturity of solutions in all phases of BCM cycle: risk analysis (a), business impact analysis (b), BCM plans and strategies (c), BCM implementation (d), testing and updating BCM (e) and maintaining BCM (f)) is higher than in organizations, which have not implemented Controlling.

All developed hypotheses, showing the character of the relation between Controlling and BCM and their influence on organizational results, are presented on Fig. 1.

\section{RESEARCH METHODOLOGY AND RESULTS}

The survey was conducted in order to verify the proposed hypotheses and identify the level of BCM maturity, BCM use, Controlling use, benefits obtained due to BCM implementation and organizational performance for every considered organization in two business contexts. The main survey was preceded by the pilot survey conducted in early 2018 among the group of 50 organizations in order to explain the issues concerning ambiguity of several questions. The main research was conducted as a part of a research project "The IT reliability influence on the quality of management methods and techniques", no. 2017/01/X/HS4/01967 financed from the funds of the National Science Center in Poland in March 2018, among organizations located in Poland and Switzerland, which was the only condition limiting the sample (organizations were surveyed regardless of size, industry or type of business etc.), using online survey service: SurveyMonkey. Only one survey was carried out anonymously in one organization, and it was completed by employees who have a broad view of the entire organization.

The research sample contains the organizations operating in Poland and Switzerland. 558 valid responses were collected from Poland and 564 valid responses were collected from Switzerland. The sample cannot be considered as representative, since the population of organizations operating in those two countries is finite but very large and the method of including organization in the sample do not supported its representativeness. However, it is sufficiently diversified to be a basis for overall conclusions concerning the given topic. Sample characteristics are presented in Table 1 clearly show that the sample is covering organizations of all sizes and all types. They are scattered quite evenly between all sizes (and all main sources of revenue), which confirms that the sample allows for formulation of conclusions concerning the studied relations and is sufficient for verification of formulated hypotheses. The selection of organizations from two countries is intentional and is aimed at including into the sample organizations assessing their BCM and organizational performance as rather insufficient (below 3), from developing economy and at the beginning of the process of BCM implementation (which is the case for Poland) and those assessing $\mathrm{BCM}$ and organizational performance as generally good (above 3), from developed economy and with more mature and aligned BCM. It allows for obtaining more valuable results differentiating the maturity level of BCM among the sample as a basis for hypotheses verification.

Table 1. Research sample characteristics.

\begin{tabular}{lcccc}
\hline Organization size & $\begin{array}{c}\text { Manufacturing } \\
\text { organizations }\end{array}$ & $\begin{array}{c}\text { Service } \\
\text { organizations }\end{array}$ & $\begin{array}{c}\text { Trade } \\
\text { organizations }\end{array}$ & Total \\
\hline Micro (below 10 people) & 130 & 64 & 27 & 221 \\
Small (11-50 people) & 87 & 144 & 43 & 274 \\
Medium (51-250 people) & 63 & 112 & 73 & 248 \\
Large (above 250 people) & 120 & 184 & 75 & 379 \\
Total & 400 & 504 & 218 & 1122 \\
\hline \multicolumn{4}{c}{ Source: (Tworek \& Zabłocka-Kluczka 2018b) } & \\
\end{tabular}

\subsection{Variables measurement}

In order to examine the proposed hypotheses, key variables were defined: Controlling use, BCM use, BCM maturity, benefits obtained due to BCM implementation and organizational performance.

Controlling use was measured taking into consideration the respondent answer to the question: is Controlling implemented in the organization as one of management methods? It is a dichotomous variable, which is obtaining the value $=1$ when Controlling is not implemented in organization and value $=2$ when
Controlling in implemented in organization. Similarly, the variable $B C M$ use was measured.

Variable BCM maturity was build basing on twodimensional matrix of BCM maturity evaluation described in [39], which is based on assumption that $\mathrm{BCM}$ is a six steps iterative process (consisting of risk analysis, business impact analysis, BCM plans and strategies formulation, BCM implementation, testing and updating $\mathrm{BCM}$, maintaining $\mathrm{BCM}$ ) and can be evaluated according to classical five levels of maturity. Each item building BCM maturity was valuated separately using a 5-grade Likert scale corresponding to the following levels of the tested solutions maturity (from ad hoc, managed, defined, integrated to 
optimized, as the intentions of researchers was to identify which component of BCM is influenced by Controlling the most.

Respondents were asked to evaluate the benefits obtained due to BCM implementation in the organization based on the list of factors using the Likert scale (from I strongly agree to I strongly disagree with the middle point: I do not have an opinion). These factors were grouped according to the type of expected benefits referring to: "...ensuring:

- continuity of technological operations (i.e. the configuration of available resources and available infrastructure, so that in the event of disruptions they enable the resumption of operations of the organization as soon as possible (acceptable)), which in turn is the basis for ensuring:

- continuity of operational / business activities (i.e. the situation when customer orders are executed without delays, and business processes run smoothly),

- continuity of market activities (i.e. maintaining a stable sales volume, a positive image of the organization on the market and good relations with market partners),

- continuity of financial activities (i.e. undisturbed financing of investment), which is a derivative of two previous phenomena.

(...) [and - Authors note] to business-related practices that are inconsistent with integrity policy, ensure protection of key interests of the owners and eliminate the risk of corrupt and non-transparent activities" [36] So generally, the variable consists of five elements: operational benefits (3 items), market benefits (4 items), technical benefits (4 items), financial benefits (2 items) and general benefits (1 item) which together build benefits obtained due to BCM implementation.

Organizational performance was measured based on integrated social, economic and environmental performance adopted from [17]. A 11-items scale was developed [9], which captures the extent to which organizations achieve economic performance (including financial and non-financial measures and short-term and long-term measures), environmental performance (including contribution to reducing negative impacts that its activities may have on the biophysical environment) and social performance (including positive participation in creating healthy and friendly communities by implementing socially responsible business practices). The evolution of the performance during the previous three years was conducted. In line with literature, subjective measures of organizational performance were used [2]. On the one hand, the objective performance measures (such as financial) are difficult to obtain due to confidentiality or unavailability. On the other, a subjective examination, although always exposed to errors, facilitates the comparison of many different organizations due to the studied aspects. Finally, there are evidence that subjective and objective performance measures are strongly correlated [14]. For this purpose, the organizational performance was rated on the Likert scale (from well below expectations to well above expectations with the middle point: as expected). Both benefits obtained due to BCM implementation and organizational performance are considered in the article as organizational results.

\subsection{Descriptive statistics and reliability analysis of scales}

As a first step in a research process, the reliability of scales of each variable was verified. The results of the analysis of the reliability of the measurement scales are presented in tab. 2. It is worth underlining that Cronbach's a was high for every variable, which indicates a high internal reliability of the scales and measurements.

Table 2. Defined variables along with the results of the reliability analysis of scales.

\begin{tabular}{lcc}
\hline \multicolumn{1}{c}{ Variable } & No. of scales & Alfa-Cronbach \\
\hline Controlling use & 1 & -- \\
BCM use & 1 & -- \\
BCM maturity & 6 & 0.902 \\
Benefits obtained due to BCM implementation & 14 & 0.914 \\
Organizational Performance & 11 & 0.890 \\
\hline
\end{tabular}

Source: own work

\subsection{The influence of BCM and Controlling use on organizational performance}

As the first step of the research, before verifying the main research hypotheses, it was investigated whether there were any differences in the assessment of organizational performance between organizations, which have implemented BCM and Controlling and those, which have not. T-student test for independent samples was conducted (Table 3 shows the results). In the organizations, where Controlling was implemented, organizational performance was evaluated significantly higher than in those, which had not implemented it. Similarly, in organizations, where BCM was implemented, organizational performance was evaluated significantly higher than in those, which had not implemented it. However, the difference between organizational performance average evaluations among organizations using and not using particular method is higher in case of Controlling. It can be stated that its implementation causes higher increase of organizational performance than BCM. Therefore, the obtained results allow for accepting $\mathrm{H} 1$ and $\mathrm{H} 3$ hypotheses stating that in organizations, which have implemented Controlling, the organizational 
performance is higher than in organizations, which have not implemented it. The same statement is true for BCM.

Next, the correlation analysis between BCM maturity and organizational performance was used in order to verify hypotheses $\mathrm{H} 2$ (abcdef) and the results are shown in Table 4. They clearly show that there is a positive and statistically significant correlation between BCM maturity and organizational performance. The strongest correlation is occurring for Maintaining BCM.

Table 3. Differences in organisational performance assessment between two groups: the organisations using

\begin{tabular}{|c|c|c|c|c|}
\hline $\begin{array}{l}\text { Organizational } \\
\text { performance in } \\
\text { organization with: }\end{array}$ & $\begin{array}{c}\text { Method } \\
\text { implemented }\end{array}$ & $\begin{array}{l}\text { Method not } \\
\text { implemented }\end{array}$ & $t$-Statistic & $\begin{array}{c}\text { Significan } \\
\text { ce level }\end{array}$ \\
\hline $\mathrm{BCM}$ & $\begin{array}{l}\mathrm{N}=992 \\
\mathrm{M}=3.42 \\
\mathrm{SD}=0.87\end{array}$ & $\begin{array}{l}\mathrm{N}=120 \\
\mathrm{M}=2.59 \\
\mathrm{SD}=1.02\end{array}$ & $t(1110)=-9.659$ & $p<0.01$ \\
\hline Controlling & $\begin{array}{l}\mathrm{N}=1047 \\
\mathrm{M}=3.40 \\
\mathrm{SD}=0.87\end{array}$ & $\begin{array}{c}\mathrm{N}=72 \\
\mathrm{M}=2.26 \\
\mathrm{SD}=0.92\end{array}$ & $t(1117)=-10.660$ & $p<0.01$ \\
\hline
\end{tabular}

For other items of BCM maturity the correlation is slightly weaker but can be still considered as mild and occurring, which is an indication of a significant relation between analyzed variables. Therefore, those results are a basis for accepting entire $\mathrm{H} 2$ hypothesis confirming that there is a positive relation between BCM maturity and organizational performance.

Table 4. Correlation analysis between the IT reliability, BCM maturity and benefits obtained by organization due to BCM implementation.

\begin{tabular}{lc}
\hline BCM maturity & Performance \\
\hline Risk analysis & $\mathrm{r}(1091)=0.457^{* *}, \mathrm{p}<0.001$ \\
Business impact analysis & $\mathrm{r}(1081)=0.461^{* *}, \mathrm{p}<0.001$ \\
BCM plans and strategies & $\mathrm{r}(1085)=0.470^{* *}, \mathrm{p}<0.001$ \\
BCM implementation & $\mathrm{r}(1085)=0.442^{* *}, \mathrm{p}<0.001$ \\
Testing and updating BCM & $\mathrm{r}(1089)=0.493^{* *}, \mathrm{p}<0.001$ \\
Maintaining BCM & $\mathrm{r}(1090)=0.509^{* *}, \mathrm{p}<0.001$ \\
\hline
\end{tabular}

Source: own work

Therefore, it may be concluded that both BCM and Controlling use, as well as BCM maturity are significantly influencing the organizational performance.

\subsection{The scope and type of coexistence of BCM and Controlling}

In the second stage of the research, the scope of coexistence of BCM and Controlling was analyzed. Four possible situations were distinguished: both methods were implemented $(1,1)$, only BCM was implemented $(1,0)$, only Controlling was implemented $(0,1)$ and no method was implemented $(0,0)$. Only 38 organizations from the sample (1140 organizations in total) did not declare the use of any of the analyzed methods. BCM was used as an independent management method in 36 organizations, and Controlling was used independently in 83 of them. Both methods were used in 983 organizations. For the analysis of the coexistence of BCM with Controlling against the absence of them (i.e. using only one method or the absence of both methods), cross tables and chi-square statistics were used, assuming a critical level of significance of 0.05 . The obtained results show that the most common is the situation, when both methods are used. The results of statistical analyzes (cross tables, chi-square test) show that the differences among groups identified for the BCM and Controlling coexistence are statistically significant $\left(X^{2}=138.425 ; p\right.$ $=0.001$ ).

In order to verify the $\mathrm{H} 4 \mathrm{a}$ hypothesis, the analysis of variance was used. Results of One-Way ANOVA concerning the coexistence of BCM with Controlling and organisational performance are presented in Table 5.

Table 5. Results of One-Way ANOVA concerning the coexistence of BCM with Controlling and organisational performance

\begin{tabular}{|c|c|c|c|c|c|}
\hline Coexistance of BCM and Controlling & $\mathbf{N}$ & M & SD & Sig. lev. & F statistic \\
\hline$(1,1)$ BCM yes, Controlling yes & 956 & 3.45 & 0.86 & 0.002 & \multirow{4}{*}{$\begin{array}{c}F(34.1118)=5.35 \\
p<0.001\end{array}$} \\
\hline$(1,0)$ BCM yes, Controlling no & 35 & 2.66 & 0.71 & 0.011 & \\
\hline$(0,1) \mathrm{BCM}$ no, Controlling yes & 83 & 2.90 & 0.90 & 0.000 & \\
\hline$(0,0)$ BCM no, Controlling no & 37 & 1.89 & 0.95 & - & \\
\hline
\end{tabular}

The results show statistically significant differences between groups. Therefore, H4a hypothesis should be accepted, stating that in organizations that declare the simultaneous implementation of BCM and Controlling, 
the organizational performance will be higher than in organizations, which have implemented only one of the analyzed methods. The highest organizational performance was achieved for the situation when both management methods were implemented. This shows the complementarity of both methods. At the same time, it should be noted that the difference in the value of the organizational performance for the situation when the Controlling itself was implemented and the situation when both methods were implemented is smaller than the difference in value between the organizational performance for the BCM itself and the situation when both methods were implemented. This may prove the superiority of $\mathrm{BCM}$ in relation to Controlling. BCM benefits more from the implementation of Controlling than Controlling from the implementation of BCM. Controlling can therefore be considered a tool to help BCM achieve its goals.

In order to verify the $\mathrm{H} 4 \mathrm{~b}$ hypothesis, the analysis of independent samples using t-student test was conducted (Table 6 shows the results). Benefits obtained due to BCM implementation were evaluated significantly higher in organizations, which have implemented Controlling on top of the BCM.

Table 6. Differences in benefits obtained due to BCM implementation assessment between two groups of organization with BCM: the organisations using Controlling and the organisations without Controlling - t-statistic was

\begin{tabular}{|c|c|c|c|c|}
\hline $\begin{array}{l}\text { Benefits obtained } \\
\text { due to } B C M\end{array}$ & $\begin{array}{l}\text { Controlling } \\
\text { implemented }\end{array}$ & $\begin{array}{l}\text { Controlling } \\
\text { not } \\
\text { implemented }\end{array}$ & $t$-Statistic & $\begin{array}{c}\text { Significance } \\
\text { level }\end{array}$ \\
\hline implementation & $\begin{array}{l}N=855 \\
M=3.01 \\
S D=1.09\end{array}$ & $\begin{array}{c}N=51 \\
M=2.31 \\
S D=0.82\end{array}$ & $\mathrm{t}(904)=-4.52$ & $p<0.01$ \\
\hline
\end{tabular}

The results show statistically significant differences between groups. Therefore, H4b hypothesis should be accepted, stating that in organizations that declare the simultaneous implementation of BCM and Controlling, benefits obtained due to BCM implementation are higher than in organizations, which have implemented BCM and have not implemented Controlling. A higher value of benefits obtained due to $B C M$ implementation is occurring in the case when Controlling is implemented next to the BCM in the organization. Again, this proves the positive impact of Controlling on the implementation of BCM goals.

\subsection{Controlling, BCM maturity, benefits obtained due to BCM implementation and organizational performance}

The relation between BCM maturity and organizational results (organizational performance and benefits obtained due to BCM implementation) was analyzed in the context of Controlling use to verify whether this variable is a statistically significant moderator of the relations, which existence is verified above. Regression analysis with moderator was used to determine that. The results of the analysis are presented in table 7 .

The statistical reasoning was based on the same procedure in case of all hypotheses (formulated for each of 6 items building BCM maturity). In every case, as a first step, new variable - moderator - is introduced. The moderator variable is built as a product of two standardized independent variables (BCM maturity item and Controlling use as a second independent variable). As a second step, 3 regression models are built for every case (the analysis was performed using Process macro for IBM SPSS Statistics). The first model is built as a base model for comparison, only independent variables (Controlling use as a second independent variable) are added as predictors. The second model is built using independent variables (Controlling use still as a second independent variable) together with the moderator as predictors to verify whether the moderating influence is occurring in sample. To confirm that, the third regression model is built using only one independent variable (without Controlling use as a second independent variable) and the moderator as predictors.

In all six cases, the obtained models are statistically significant. The Controlling use is a moderator of analyzed relation in case of 2 items. In case of risk analysis and results obtained due to BCM implementation (hypothesis $\mathrm{H} 5 \mathrm{a}$ ), the obtained model is statistically significant but delta R2 is insignificant and moderator is an insignificant variable in the model ( $p=$ $0.185)$.

In case of business impact analysis and results obtained due to BCM implementation (hypothesis $\mathrm{H} 5 \mathrm{~b}$ ), the situation is the same ( $p=0.209)$. In case of BCM plans and strategies and results obtained due to BCM implementation (hypothesis $\mathrm{H} 5 \mathrm{c}$ ) and BCM implementation and results obtained due to BCM implementation (hypothesis $\mathrm{H} 5 \mathrm{~d}$ ), the delta $\mathrm{R} 2$ and obtained models are statistically significant and the moderator is a significant variable in all of those models.

In case of testing and updating $\mathrm{BCM}$ and results obtained due to BCM implementation (hypothesis $\mathrm{H} 5 \mathrm{e}$ ), the obtained model is statistically significant but delta $\mathrm{R} 2$ is insignificant and moderator is an insignificant variable in the model $(p=0.059)$. In case of maintaining $\mathrm{BCM}$ and results obtained due to BCM implementation (hypothesis $\mathrm{H} 5 \mathrm{f}$ ), the obtained model is statistically significant but delta $\mathrm{R} 2$ is also insignificant and moderator is an insignificant variable in the model ( $p=$ $0.147)$.

Therefore, obtained results are the basis for acceptance of hypotheses $\mathrm{H} 5 \mathrm{c}, \mathrm{H} 5 \mathrm{~d}$, confirming that Controlling use is a moderator for the relation between 2 items of BCM maturity: plans and strategies, implementation, and benefits obtained due to BCM implementation. 
Table 7. Regression models' statistics for benefits obtained due to BCM implementation

\begin{tabular}{|c|c|c|c|c|c|}
\hline Model description & $\begin{array}{c}\text { F-Snedecor model } \\
\text { description }\end{array}$ & $\mathbf{R}^{2}$ & $\begin{array}{c}\text { Delta } \\
\mathbf{R}^{2}\end{array}$ & $\begin{array}{l}\text { Moderator } \\
\text { coeff. }\end{array}$ & $\begin{array}{c}\mathbf{P} \\
\text { Value }\end{array}$ \\
\hline $\begin{array}{l}\text { Controlling use, } \\
\text { BCM maturity - risk analysis, } \\
\text { Moderator } \\
\text { dependent } v .: \text { benefits obtained due to } B C M \\
\text { implementation }\end{array}$ & $\begin{array}{l}F(3,1074)=148.313 \\
p<0.001\end{array}$ & 0.292 & 0.002 & 0.1285 & 0.1852 \\
\hline $\begin{array}{l}\text { Controlling use, } \\
\text { BCM maturity - business impact analysis, } \\
\text { Moderator } \\
\text { dependent } v \text {.: benefits obtained due to BCM } \\
\text { implementation }\end{array}$ & $\begin{array}{l}F(3,1065)=126.441 \\
p<0.001\end{array}$ & 0.163 & 0.001 & 0.1359 & 0.2095 \\
\hline $\begin{array}{l}\text { Controlling use, } \\
\text { BCM maturity - BCM plans and strategies, } \\
\text { Moderator } \\
\text { dependent } v .: \text { benefits obtained due to BCM } \\
\text { implementation }\end{array}$ & $\begin{array}{l}F(3,1070)=140.045 \\
p<0.001\end{array}$ & 0.281 & 0.038 & 0.2039 & 0.0178 \\
\hline $\begin{array}{l}\text { Controlling use, } \\
\text { BCM maturity - BCM implementation, } \\
\text { Moderator } \\
\text { dependent } v .: \text { benefits obtained due to BCM } \\
\text { implementation }\end{array}$ & $\begin{array}{l}F(3,1072)=160.753 \\
p<0.001\end{array}$ & 0.310 & 0.004 & 0.1921 & 0.0123 \\
\hline $\begin{array}{l}\text { Controlling use, } \\
\text { BCM maturity - testing and updating BCM, } \\
\text { Moderator } \\
\text { dependent } v .: \text { benefits obtained due to BCM } \\
\text { implementation }\end{array}$ & $\begin{array}{l}F(3,1072)=205.264 \\
p<0.001\end{array}$ & 0.365 & 0.002 & 0.1516 & 0.0594 \\
\hline $\begin{array}{l}\text { Controlling use, } \\
\text { BCM maturity - maintaining BCM, } \\
\text { Moderator } \\
\text { dependent } v .: \text { benefits obtained due to BCM } \\
\text { implementation }\end{array}$ & $\begin{array}{l}F(3,1073)=223.199 \\
p<0.001\end{array}$ & 0.384 & 0.001 & 0.1204 & 0.1474 \\
\hline
\end{tabular}

Source: own work.

The results of the analysis if the Controlling use is a between BCM maturity and organizational performance statistically significant moderator of the relations relation are presented in table 8.

Table 8. Regression models' statistics for organizational performance

\begin{tabular}{|c|c|c|c|c|c|}
\hline Model description & $\begin{array}{c}\text { F-Snedecor model } \\
\text { description }\end{array}$ & $\mathbf{R}^{2}$ & $\begin{array}{c}\text { Delta } \\
R^{2}\end{array}$ & $\begin{array}{l}\text { Moderator } \\
\text { coeff. }\end{array}$ & $\begin{array}{c}\mathbf{P} \\
\text { Value }\end{array}$ \\
\hline $\begin{array}{l}\text { Controlling use, } \\
\text { BCM maturity - risk analysis, } \\
\text { Moderator } \\
\text { dependent v.: organizational performance }\end{array}$ & $\begin{array}{l}F(3,1086)=116.542 \\
p<0.001\end{array}$ & 0.243 & 0.001 & 0.1353 & 0.1361 \\
\hline $\begin{array}{l}\text { Controlling use, } \\
\text { BCM maturity - business impact analysis, } \\
\text { Moderator } \\
\text { dependent } v \text {.: organizational performance }\end{array}$ & $\begin{array}{l}F(3,1076)=121.163 \\
p<0.001\end{array}$ & 0.252 & 0.063 & 0.2976 & 0.0026 \\
\hline $\begin{array}{l}\text { Controlling use, } \\
\text { BCM maturity - BCM plans and strategies, } \\
\text { Moderator } \\
\text { dependent v.: organizational performance }\end{array}$ & $\begin{array}{l}F(3,1080)=128.644 \\
p<0.001\end{array}$ & 0.263 & 0.044 & 0.2029 & 0.0108 \\
\hline $\begin{array}{l}\text { Controlling use, } \\
\text { BCM maturity - BCM implementation, } \\
\text { Moderator } \\
\text { dependent v.: organizational performance }\end{array}$ & $\begin{array}{l}F(3,1080)=118.319 \\
p<0.001\end{array}$ & 0.247 & 0.029 & 0.1508 & 0.0406 \\
\hline $\begin{array}{l}\text { Controlling use, } \\
\text { BCM maturity - testing and updating BCM, } \\
\text { Moderator } \\
\text { dependent v.: organizational performance }\end{array}$ & $\begin{array}{l}F(3,1084)=139.670 \\
p<0.001\end{array}$ & 0.278 & 0.003 & 0.1145 & 0.4802 \\
\hline $\begin{array}{l}\text { Controlling use, } \\
\text { BCM maturity - maintaining BCM, } \\
\text { Moderator } \\
\text { dependent } v . \text { : organizational performance }\end{array}$ & $\begin{array}{l}F(3,1085)=153.241 \\
p<0.001\end{array}$ & 0.297 & 0.002 & 0.1490 & 0.0689 \\
\hline
\end{tabular}


In all six cases, the obtained models are statistically significant. The Controlling use is a moderator of analyzed relation in case of 3 items. In case of risk analysis and organizational performance (hypothesis $\mathrm{H6a}$ ), the obtained model is statistically significant but delta R2 is insignificant and moderator is an insignificant variable in the model $(p=0.136)$. In case of business impact analysis and organizational performance (hypothesis $\mathrm{H} 6 \mathrm{~b}$ ), BCM plans and strategies and organizational performance (hypothesis $\mathrm{H} 6 \mathrm{c}$ ) and BCM implementation and organizational performance (hypothesis $\mathrm{H} 6 \mathrm{~d}$ ), the delta R2 and obtained models are statistically significant and the moderator is a significant variable in all of those models. In case of testing and updating BCM and organizational performance (hypothesis $\mathrm{H} 6 \mathrm{e}$ ), the obtained model is statistically significant but delta $R 2$ is insignificant and moderator is an insignificant variable in the model $(p=0.481)$. In case of maintaining BCM and organizational performance (hypothesis $\mathrm{H} 6 \mathrm{f}$ ), the obtained model is statistically significant but delta R2 is also insignificant and moderator is an insignificant variable in the model $(p=0.069)$. Therefore, obtained results are the basis for acceptance of hypotheses $\mathrm{H} 6 \mathrm{~b}$, $\mathrm{H} 6 \mathrm{c}$, H6d, confirming that Controlling use is a moderator for the relation between 3 items of BCM maturity: business impact analysis, plans and strategies, implementation, and organizational performance.

\subsection{Controlling use and BCM maturity}

As a final step, the verification of $\mathrm{H} 7$ hypothesis was performed using the analysis of independent samples using t-student test was conducted (Table 9 shows the results). BCM Maturity were evaluated significantly higher in organizations, which have implemented Controlling on top of the BCM.

Table 9. Differences in BCM maturity assessment between two groups of organization with BCM: the organisations using Controlling and the organisations without Controlling - t-statistic was used.

\begin{tabular}{|c|c|c|c|c|}
\hline $\begin{array}{l}\text { BCM maturity in } \\
\text { organization with } \\
\text { BCM and Controlling: }\end{array}$ & $\begin{array}{l}\text { Controlling } \\
\text { implemented }\end{array}$ & $\begin{array}{c}\begin{array}{c}\text { Controlling } \\
\text { not } \\
\text { implemented }\end{array} \\
\end{array}$ & $t$-Statistic & $\begin{array}{c}\text { Significance } \\
\text { level }\end{array}$ \\
\hline Risk analysis & $\begin{array}{l}N=855 \\
M=3.19 \\
S D=1.28\end{array}$ & $\begin{array}{c}N=51 \\
M=1.71 \\
S D=1.08\end{array}$ & $t(904)=-9.45$ & $p<0.01$ \\
\hline $\begin{array}{l}\text { Business impact } \\
\text { analysis }\end{array}$ & $\begin{array}{l}\mathrm{N}=855 \\
\mathrm{M}=3.15 \\
\mathrm{SD}=0.99\end{array}$ & $\begin{array}{c}N=51 \\
M=1.82 \\
S D=1.19\end{array}$ & $t(904)=-9.15$ & $p<0.01$ \\
\hline $\begin{array}{l}\text { BCM plans and } \\
\text { strategies }\end{array}$ & $\begin{array}{l}N=855 \\
M=3.27 \\
S D=1.23\end{array}$ & $\begin{array}{c}N=51 \\
M=2.04 \\
S D=1.23\end{array}$ & $t(904)=-8.11$ & $p<0.01$ \\
\hline BCM implementation & $\begin{array}{l}\mathrm{N}=855 \\
\mathrm{M}=3.23 \\
\mathrm{SD}=1.24\end{array}$ & $\begin{array}{c}N=51 \\
M=2.25 \\
S D=1.37\end{array}$ & $\mathrm{t}(904)=-6.35$ & $p<0.01$ \\
\hline $\begin{array}{l}\text { Testing and updating } \\
\text { BCM }\end{array}$ & $\begin{array}{l}N=855 \\
M=3.40 \\
S D=1.30\end{array}$ & $\begin{array}{c}N=51 \\
M=2.15 \\
S D=1.29\end{array}$ & $\mathrm{t}(904)=-7.77$ & $p<0.01$ \\
\hline Maintaining BCM & $\begin{array}{l}N=855 \\
M=3.32 \\
S D=1.30\end{array}$ & $\begin{array}{c}N=51 \\
M=2.08 \\
S D=1.18\end{array}$ & $t(904)=-7.46$ & $p<0.01$ \\
\hline
\end{tabular}

The results show statistically significant differences between groups. Therefore, $\mathrm{H} 7$ hypothesis should be accepted, stating in organization, which have implemented Controlling, the maturity of BCM (in particular maturity of solutions in all phases of BCM cycle: risk analysis (a), business impact analysis (b), BCM plans and strategies (c), BCM implementation (d), testing and updating BCM (e) and maintaining BCM (f)) is higher than in organizations, which have not implemented Controlling.

A higher value of BCM Maturity is occurring in the case when Controlling is implemented next to the BCM in the organization. It allows for the final conclusion concerning the positive impact of Controlling on the implementation of BCM goals and confirmation of the complementarity of both methods with the indication of BCM superiority over Controlling.

\section{DISCUSSION}

Coexistence of the management methods seem to be a significant issue in the management of modern organizations. The main focus of this study was to verify whether the impact of BCM maturity on the organizational results is stronger in organizations, which are using Controlling as one of management methods and weaker in organizations, which are not using it. The obtained results confirm to some extent the adopted assumptions and underline the role of Controlling use in building organization's resilience.

First of all, it should be noticed that both of those methods influence organizational results. Such dependence was expected, but not obvious, as organizational performance was assessed not only from the economical perspective (financial and non-financial, short-term and long-term measures were taken into 
consideration), but also social (organization's participation in crating healthy and friendly communities by implementation responsible business practices was assessed) and environmental one (organization's contribution to reducing negative impact on environment was valuated), although still treated as a one variable. In a group of organizations declaring Controlling and / or BCM implementation, the organizational performance was evaluated significantly higher than in organizations, which have not implemented them. However, it can be stated that Controlling implementation causes higher increase of organizational performance than BCM, although in BCM case the influence on organizational performance is still noticeable. That can be easily explained from economical perspective. Controlling is a method of management support, which by definition focuses on ensuring the rationality of management and often does it by, among others, continuous verification of economic legitimacy of the adopted goals, monitoring their implementation and counteracting, when the deviations from taken standards occur, often using management accounting tools. BCM is rather not focused on ensuring organization's economic legitimacy, but on ensuring continuity of organization's functioning, which also enables the achievement of economical' goals. However, due to the fact that the organizational performance was defined so widely, the tested relations appeared also true with reference to social and environmental perspective. Considering Controlling, perceived as a comprehensive tool of steering organization's activity based on the results achieved in particular areas, it does not surprise. But in reference to BCM it should be noted that this method "...can offer to organization more than it currently does. Among the events that may threaten the continuity of the organization's existence, apart from catastrophic technical or service failures, reputational failures (caused not only by product malfunction, but also by corruption and improper organization and its member behaviour) are nowadays increasingly mentioned as significant" [36]. This last category (reputational failures) is very wide and contains i.e. negative impact on environment or irresponsible business practices. Treating them in a category of hazard or disruption (in a systematic framework of BCM) allows to realize the implication of misbehavior, i.e. the costs or loos of profit, which may appear as a result of carrying or not carrying out some operations and to understand the consequences of them. The awareness of potential losses promotes better understanding of the whole situation and in managerial context can have a positive impact on organizational performance.

The obtained results concern the interaction between chosen management methods, discussed in the context of their influence on organizational performance. The results showed that not only both of those methods influence organizational performance, but their coexistence in organization fosters higher organizational performance (in comparison to the situation when none or only one of them is implemented). This shows the complementarity of both methods. At the same time, it should be noted that BCM benefits more from the implementation of Controlling than Controlling from the implementation of BCM, as the difference in organizational performance for the situation when the Controlling itself was implemented and the situation when both methods were implemented is smaller than the difference in organizational performance for the situation when the BCM itself was implemented and the situation when both methods were implemented. As it was already underlined, this may prove the superiority of BCM in relation to Controlling. Therefore, it can be said that Controlling plays the service role towards the BCM. Controlling should be able to point out an appropriate response to interruptions and distractions so that the organization's core activities were not put at risk, mainly through investigating deviations from the adopted assumption, collecting and forwarding suitable information about potential problems that threaten organizational resilience.

The research showed that Controlling can be considered as a tool helping BCM to achieve its goals. This supposition leads to the question, if this support is indirect or if Controlling can directly affect the benefits obtained due to BCM implementation. The obtained results confirmed that higher value of benefits obtained due to BCM implementation is occurring in situation, when Controlling is implemented next to the BCM in the organization. Simultaneous implementation of BCM and Controlling fosters positive results not only for organization as a whole, but - what is more interesting - also for benefits obtained due to BCM implementation. Moreover, a higher BCM maturity is occurring in the situation, when Controlling is implemented next to the BCM in the organization. All of that clearly proves the positive impact of Controlling on the BCM maturation and implementation of BCM goals. As research showed, this applies to all six steps of iterative BCM process (risk analysis, business impact analysis, BCM plans and strategies formulation, BCM plans and strategies implementation, testing and updating BCM, maintaining BCM).

However, the main focus of this study was to verify whether the impact of BCM maturity on the benefits obtained from BCM implementation and on the organizational performance is stronger in organizations, which are using Controlling as one of management methods and weaker in organizations, which are not using it. That moderation was fully confirmed only in relation to two out of six steps of BCM process: BCM plans and strategies formulation and then their implementation. Controlling use is also a statistically significant moderator of the relation between BCM maturity and organizational performance in regard to conducting business impact analysis (BIA). BIA is the unique process, build on the risk analysis, in which the impact to the business of potential losses in meaningful, quantitative and qualitative term is valuated. It is focused on establishing the key parameters on which BC plans and preparations are based upon [10], what in a fact lies in a very heart of Controlling too. Summarizing, as it was previously underlined, 
Controlling is a method that often coexist with other management methods [6]. In this paper it was confirmed that it comes into relation of complementarity with BCM, and in a fact the superiority of BCM in relation to Controlling was observed. However, it should be noticed that Controlling, although indisputably important modern method of management support, has to offer more than it is commonly believed. Observed synergic effect can appear not only in the context of improving organizational performance as a whole, but also regarding the benefits and maturity of other management methods. It establishes interesting directions for further research.

\section{CONCLUSIONS}

The issue of the coexistence of $\mathrm{BCM}$ and Controlling and its empirical verification is not yet discussed in the literature. Both of these methods seem to be completely different in their assumptions, and yet their joint implementation leads to an interesting synergistic effect.

The empirical research was carried out in order to verify the relation between $\mathrm{BCM}$ and Controlling and analyze their coexistence. Based on the obtained results, it can be concluded that Controlling is indeed fostering the increase of organizational results obtained from BCM implementation and use. It can be concluded that Controlling may act as one of tools for BCM and strengthens the influence of its maturity on organizational performance and benefits obtained due to its implementation. Moreover, the organizations using both of these management methods are indicating higher levels of organizational performance and benefits obtained due to BCM implementation then those using BCM without the support of Controlling. It furthermore confirms the importance of Controlling use for obtaining results from using BCM.

However, it is important to underline that the research has some limitations. The above-mentioned hypotheses were verified based on only one research sample and only in two business contexts. Hence, the further verification of conclusions presented in this paper is needed. However, the obtained results seem to be a solid first step in the analysis of coexistence of Controlling and BCM in organization and establish directions for further research, which is needed in order to determine in detail the scope of Controlling support for BCM.

\section{REFERENCES}

[1] Al Hour A. (2012), Business Continuity Management. Choosing to survive, IT Governance Publishing, Cambridgeshir.

[2] Bansal, P. (2005) Evolving sustainably: A longitudinal study of corporate sustainable development. Strategic Management Journal, 26(3), pp. 197-218.

[3] Bea F., Friedl B., Schweitzer M. (2005), Allgemeine Betriebwirtschftslehre, Lucius UTB, Stuttgart.

[4] Bieńkowska A., Analiza rozwiązań i wzorce controllingu w organizacji, Oficyna Wydawnicza PWr, Wrocław, 2015.

[5] Bieńkowska A., Zgrzywa-Ziemak A. (2011), Współczesne metody zarządzania w przedsiębiorstwach funkcjonujących w Polsce - identyfikacja stanu istniejącego, [w:] Współczesne metody zarządzania w teorii i praktyce, M. Hopej, Z. Kral (red.), Oficyna Wydawnicza PWr, Wrocław.
[6] Bieńkowska A., Zgrzywa-Ziemak A. (2013), Controlling and other methods of management - the results of the empirical study in the enterprises functioning in Poland. Prace Naukowe Uniwersytetu Ekonomicznego we Wrocławiu. 2013, No 290, pp. 9-20.

[7] Bieńkowska A., Zgrzywa-Ziemak A. (2014a), Współwystępowanie koncepcji i metod zarządzania w świetle badań empirycznych. Prace Naukowe Uniwersytetu Ekonomicznego we Wrocławiu, Research Papers of Wrocław University of Economics. 2014, No 340, pp. 17-26.

[8] Bieńkowska A., Zgrzywa-Ziemak A. (2014b), Coexistence of Controlling and other management methods. Operations Research and Decisions. 2014, No 2, pp. 5-33.

[9] Boiral, O. and Henri, F. (2012) Modeling the Impacts of Corporate Commitment on Climate Change. Business Strategy and the Environment, 21(8), pp. 495-516.

[10] Burtles J., Noakes K. (eds.) (2016), Principles and Practice of Business Continuity. Tools and Techniques, 2nd edition, Rothstein Publishing, Brookfield, Connecticut, USA.

[11] Campos, L. M. S., D. A. de Melo Heizen, M. A. Verdinelli \& P. A. C. Miguel (2015) Environmental performance indicators: a study on ISO 14001 certified companies. Journal of Cleaner Production, 99, pp. 286.

[12] Chachuła D. (2009a), Controlling. Koncepcje, narzędzia, modele, Difin, Warszawa.

[13] Clarkson, P. M., Li, Y., Richardson, G. D. and Vasvari, F. P. (2008) Revisiting the relation between environmental performance and environmental disclosure: An empirical analysis". Accounting, Organizations and Society, 33(4), pp. 303-327.

[14] Dawes, J. (1999). The relationship between subjective and objective company performance measures in market orientation research: further empirical evidence. Marketing BulletinDepartment of Marketing Massey University, 10, pp. 65-75

[15] Dess, G. G. and Robinson, R. B. (1984) Measuring organizational performance in the absence of objective measures: The case of the privately held firm and conglomerate business unit. Strategic Management Journal, 5(3), pp. 265-273

[16] Elliot D., Swartz E., Herbane B. (2010), Business Continuity Management. A Crisis Management Approach, second edition, Routledge. Taylor \& Francis Group, New York and London.

[17] Epstein, M. J., Buhovac, A. R. (2014). Making sustainability work. Best practices in managing and measuring corporate social, environmental, and economic impacts. Berrett-Koehler Publishers, San Francisco.

[18] Hahn D., Hungenberg H. (2001), Planung und Kontrolle Planungs- und Kontrollsysteme - Planungs- und Kontrollerechtung. Wertorientierte Controllingkonzepte, 6. Aufl., Springer Gabler, Wiesbaden.

[19] Herbane B., Elliott D., Swartz E.M. (2004), Business continuity management: time for strategic role?, Long Range Planning, Vol. 37 , No. 5, 2004, pp. 435-457.

[20] Hongming, X. I. E., L. I. U. Changyong \& C. Chunhui (2007) Relationships among market orientation, learning orientation, organizational innovation and organizational performance: An empirical study in the Pearl River Delta region of China. Frontiers of business research in China, 1, pp. 222.

[21] Jagoda H., 1999, Koncepcje przekrojowe w zarządzaniu przedsiębiorstwem. Więcej pytań czy odpowiedzi?, "Przegląd Organizacji", № 2, pp. 10-12.

[22] Järveläinen J. (2013), IT incidents and business impacts: Validating a framework for continuity management in information systems, International Journal of Information management, Vol. 33, 2013, pp. 583-590.

[23] Kuc B.R. (2006), Kontroling narzędziem wczesnego ostrzegania, Wyd. Menedżerskie PTM, Warszawa.

[24] Kuc B.R. (2011), Kontroling dla menedżerów, Helion, Warszawa.

[25] Labaka L., Hernantes J., Sarriegi J.M. (2016), A holistic framework for building critical infrastructure resilience, Technological Forecasting \& Social Change, Vol. 103, pp. 21-33.

[26] Lichtarski J., Czura M. (2002), O relacjach między koncepcjami zarządzania przedsiębiorstwem, Przegląd Organizacji, 10, pp.79.

[27] Major A. (1998), System Controllingu w przedsiębiorstwie, Semper, Warszawa.

[28] Maletic, M., Maletic, D., Dahlgaard, J., Dahlgaard-Park, S. and Gomišcek, B. (2015) Do corporate sustainability practices 
[29] enhance organizational economic performance?. International Journal of Quality and Service Sciences, 7(2), pp. 184-200.

[30] Marciniak S. (2008), Controlling. Teoria, zastosowania, Difin, Warszawa.

[31] Matić, I. (2012). Measuring the effects of learning on business performances: Proposed performance measurement model. The Journal of American Academy of Business, Cambridge, 18, pp. 278.

[32] McKenzie, S. (2004) Social sustainability: towards some definitions. Hawke Research Institute Working Paper Series No 27.

[33] Nowosielski S. (2001), Centra kosztów i centra zysku w przedsiębiorstwie, Wyd. Akademii Ekonomicznej im. Oskara Langego we Wrocławiu, Wrocław.

[34] Perović V., Nerandžić B., Todorovic, A., (2012), Controlling as a useuful managament instrument in crisis times, African Journal of Business Management, Vol.6 (6), pp. 2101-2106 ISSN 19938233

[35] Perović, V., Osmanagić-Bedenik, N., Bojanić, R. and TodorovićDudić, A., (2016), Recent situation of controlling in Serbia and comparation with its implementation in Croatia, AUDITOR, 19 (76), pp. 39-48 ISSN: 2620-1461

[36] Randeree K., Mahal A., Narwani A. (2012), A business continuity management maturity model for the UAE banking sector, Business process management journal, Vol. 18, No. 3, pp. 472492.
[37] Sierpińska M., Niedbała B. (2003), Controlling operacyjny w przedsiębiorstwie, PWN, Warszawa.

[38] Skrzypek A. (2013), Effectiveness and Maturity of Quality Oriented Organizations, Rural Development, ISSN 2345-0916.

[39] Tworek K., Zabłocka-Kluczka A. (2018a), IT reliability influence on organizational benefits from business continuity management, Proceedings of International Multidisciplinary Scientific Conference on Social Science SGEM 2018.

[40] Tworek K., Zabłocka-Kluczka A. (2018b), IT reliability as a moderator of relation between Business Continuity Management maturity and benefits obtained from its implementation, IBIMA Proceedings 2018, in press.

[41] Tworek K., Zabłocka-Kluczka A. (2018c), IT reliability in organization as a factor influencing BCM maturity, Conference Proceedings: Zdolności Dynamiczne 2018, in press.

[42] Vallance, S., Perkins, H. C. and Dixon, J. E. (2011). What is social sustainability? A clarification of concepts. Geoforum, 42(3), pp. 342-348.

[43] Vollmuth H.J. (2000), Controlling. Planowanie, kontrola, zarządzanie, Placet, Warszawa

[44] Weber J. (1995), Einführung in das Controlling, 6. Aufl., Schäffer-Poeschel Verlag, Stuttgart.

[45] Weber J. (2001), Wprowadzenie do controllingu, Oficyna Wydawnicza Profit, Katowice.

\title{
Koegzistencija upravljanja i kontrole kontinuiteta poslovanja: Kontrola korišćenja kao moderator odnosa između UKP zrelosti i rezultata organizacije
}

\author{
Katarzyna Tworek, Agnieszka Bieńkowska, Anna Zabłocka-Kluczka
}

Primljen (23.11.2018.); Recenziran (09.01.2019.); Prihvaćen (04.02.2019.)

\section{Apstrakt}

Rad je posvećen analizi uticaja upotrebe kontrolinga na upravljanje kontinuitetom poslovanja (UKP). Analiza se koncentriše na UKP zrelost i njen uticaj na organizacione rezultate. Pretpostavlja se da je upotreba kontrolinga jedan od faktora koji utiču na taj odnos. Empirijska istraživanja se sprovode kako bi se proverile formulisane hipoteze na temelju rezultata dobijenih iz više od 1000 organizacija iz dva poslovna konteksta (Poljska $i$ Śvajcarska), kako bi se utvrdilo da li je korišćenje kontrolinga moderator odnosa između UKP zrelosti i organizacionih rezultata.

Ključne reči: Upravljanje kontinuitetom poslovanja, UKP zrelost, Kontroling, menadžment, organizacioni rezultati 